If

LIPI

Berita

Biologi

Jurnal IImu-ilmu Hayati

\section{E-ISSN 2337-8751}

Terakreditasi Peringkat 2

21/E/KPT/2018

Volume 19 Nomor 1, April 2020
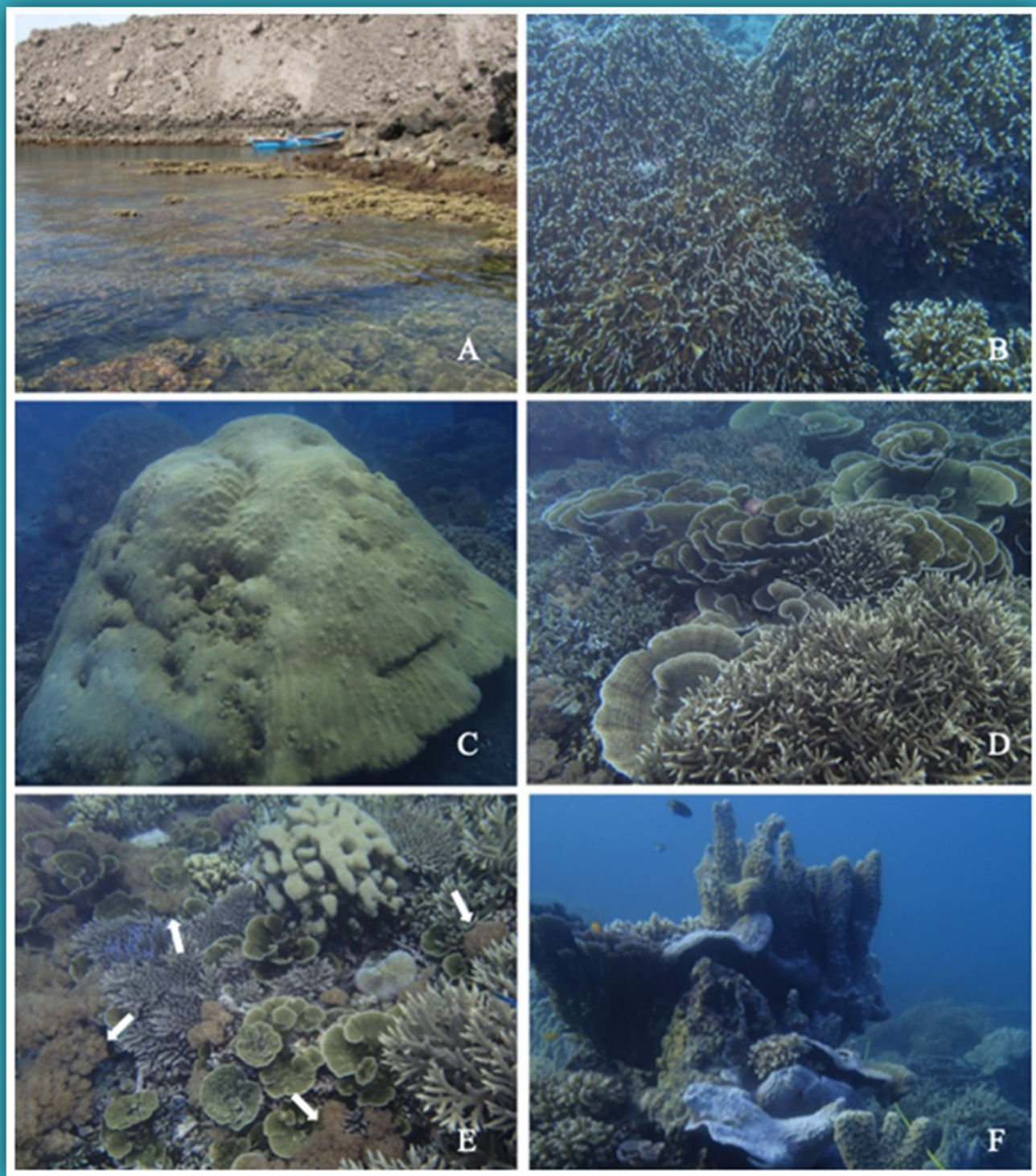


\title{
BERITA BIOLOGI
}

Vol. 19 No. 1 April 2020

Terakreditasi Berdasarkan Keputusan Direktur Jendral Penguatan Riset dan Pengembangan, Kemenristekdikti RI No. 21/E/KPT/2018

\section{Tim Redaksi (Editorial Team)}

Andria Agusta (Pemimpin Redaksi, Editor in Chief)

(Kimia Bahan Alam, Pusat Penelitian Biologi - LIPI)

Kusumadewi Sri Yulita (Redaksi Pelaksana, Managing Editor)

(Sistematika Molekuler Tumbuhan, Pusat Penelitian Biologi - LIPI)

Gono Semiadi

(Mammalogi, Pusat Penelitian Biologi - LIPI)

Atit Kanti

(Mikrobiologi, Pusat Penelitian Biologi - LIPI)

Siti Sundari

(Ekologi Lingkungan, Pusat Penelitian Biologi - LIPI)

Arif Nurkanto

(Mikrobiologi, Pusat Penelitian Biologi - LIPI)

Kartika Dewi

(Taksonomi Nematoda, Pusat Penelitian Biologi - LIPI)

Dwi Setyo Rini

(Biologi Molekuler Tumbuhan, Pusat Penelitian Biologi - LIPI)

\section{Desain dan Layout (Design and Layout)}

Liana Astuti

\section{Kesekretariatan (Secretary)}

Nira Ariasari, Budiarjo

\author{
Alamat (Address) \\ Pusat Penelitian Biologi-LIPI \\ Kompleks Cibinong Science Center (CSC-LIPI) \\ Jalan Raya Jakarta-Bogor KM 46, \\ Cibinong 16911, Bogor-Indonesia \\ Telepon (021) 8765066 - 8765067 \\ Faksimili (021) 8765059 \\ Email: berita.biologi@mail.lipi.go.id \\ jurnalberitabiologi@yahoo.co.id \\ jurnalberitabiologi@gmail.com
}

Keterangan foto cover depan: Stony corals community on the shallow-waters of the Krakatau Islands (Notes of cover picture): Komunitas karang batu pada perairan dangkal Kepulauan Krakatau 114 (as in page 114). 
P-ISSN 0126-1754

E-ISSN 2337-8751

Terakreditasi Peringkat 2

21/E/KPT/2018

LIPI

Volume 19 Nomor 1, April 2020

Berita

Biologi

Jurnal Ilmu-ilmu Hayati 


\section{Ucapan terima kasih kepada \\ Mitra Bebestari nomor ini 19(1) - April 2020}

Prof. Dr. Ir. Sulistiono, M.Sc.

(Biologi Perikanan, FPIK-Institut Pertanian Bogor )

Prof. Dr. Partomuan Simanjuntak M.Sc.

(Kimia organik, Pusat Penelitian Bioteknologi-LIPI)

Dr. Haryono, M.Si.

(Ekologi dan Budidya ikan, Pusat Penelitian Biologi-LIPI)

Dr. Nurainas

(Taksonomi Tumbuhan, FMIPA-Universitas Andalas)

Dr. Ir. Eddy Supriyono, M.Sc.

(Budidaya Perairan/Akuakultur, Fakultas Perikanan dan Ilmu Kelautan-IPB)

Dr. Lif. Sc. I Nengah Suwastika, M.Sc.

(Biologi Sel dan Molekul, FMIPA- Universitas Tadulako)

Dr. Wawan Sujarwo

(Etnobotani, Balai Konservasi Tumbuhan Kebun Raya Cibodas-LIPI)

Prof. Dr. Muhammad Hanafi, M.Sc.

(Kimia Bahan Alam, Pusat Penelitian Kimia-LIPI)

Fajarudin Ahmad, M.Si.

(Genetika tumbuhan, Pusat Penelitian Biologi-LIPI)

Dr. Tatang Mitra Setia, M.Si.

(Primatologi/Biologi Konservasi/Perilaku Hewan, Universitas Nasional)

Dr. R. Taufiq Purna Nugraha

(Manajemen Satwa Liar, Pusat Penelitian Biologi-LIPI)

Tri Aryono Hadi S.Si., M.Sc.

(Marine Biology, Pusat Penelitian Oseanografi-LIPI)

Dr. rer. nat. Edwin Setiawan S.Si., M.Sc.

(Taksonomi dan Sistematika Spons, Fakultas Sains- ITS)

Aninda Retno Utami Wibowo S.Si.

(Botani/Orchidaceae, Pusat Penelitian Konservasi Tumbuhan dan Kebun Raya-LIPI)

Dr. Widhi Dyah Sawitri

(Biokimia/Biologi Molekuler, Fakultas Pertanian, Universitas Gajah Mada)

Dr. Riza Arief Putranto, DEA

(Biologi Molekuler, PT Riset Perkebunan Nusantara) 


\title{
PEMANFAATAN RUANG VERTIKAL PADA AKTIVITAS HARIAN ORANGUTAN (Pongo pygmaeus wurmbii) DI STASIUN RISET CABANG PANTI TAMAN NASIONAL GUNUNG PALUNG, KALIMANTAN BARAT
} [Utilization of Vertical Spaces in Orangutans (Pongo pygmaeus wurmbii) Daily Activities in Cabang Panti Research Station, Gunung Palung National Park, West Kalimantan]

\author{
Awit Mulyawarman ${ }^{1^{*}}$, Tri Rima Setyawati ${ }^{2}$ dan Riyandi ${ }^{3}$ \\ ${ }^{1}$ Program Studi Biologi, Fakultas Matematika dan Ilmu Pengetahuan Alam \\ ${ }^{2}$ Universitas Tanjungpura, Jl Prof. Dr. Hadari Nawawi, Pontianak, 78124, Indonesia \\ email: awitmulyawarmannn@gmail.com
}

\section{ABSTRACT}

Orangutans are solitary animals from the Pongidae family. There are three sub-species of Bornean orangutans, i.e. Pongo pygmaeus wurmbii, $P$. pygmaeus pygmaeus and $P$. pygmaeus morio, all of which are highly endangered. Orangutans carry out several daily activities such as eating, moving, resting, and nesting in the tree canopy. However, it has yet remains unknown on how their behaviours vary with tree height. This study aimed to determine the frequency of presence, daily activities of orangutans, and vertical space utilization in orangutan activities in the natural habitat of the Panti Branch Research Station, Gunung Palung National Park. This study used the Focal Animal Sampling method with a two minute time interval for \pm 12 hours and was studied for over six months. The focal orangutans whose activities were recorded during the study consisted of 12 individuals divided into 3 age groups, namely the adult, adolescent, and juvenile age groups. The results showed that the daily activity of orangutan was observed on 36 species of trees with the greatest frequency found on Garcinia sp. and Syzigium sp. accounted for 33\% each. The female orangutans were found to be more dominant in feeding activities (3.93 per day), while male orangutans spent more time for resting activities ( 4.56 hours per day). The utilization of vertical space in young male orangutans took place in tall trees and eating activities occurred at an altitude of $33.6 \mathrm{~m}$. On average, teenage female orangutans choose tree to make their nests in trees $30 \mathrm{~m}$ high.

Keywords: daily activity, orangutan, vertical space, gunung palung

ABSTRAK

Orangutan merupakan hewan soliter dari famili Pongidae. Orangutan Kalimantan terdiri dari 3 sub spesies yaitu Pongo pygmaeus wurmbii, $P$. pygmaeus pygmaeus dan P. pygmaeus morio yangberstatus sangat terancam punah.Orangutan melakukan aktivitas sehari-harinya yang meliputi makan, bergerak, istirahat, dan bersarang.Dalam melakukan aktivitas hariannya, orangutan memanfaatkan tajuk pada pohon disekitarnya.Penelitian ini bertujuan untuk mengetahui frekuensi kehadiran, aktivitas harian orangutan, dan pemanfaatan ruang vertikal pada aktivitas orangutan di habitat alami Stasiun Riset Cabang Panti, Taman Nasional Gunung Palung.Penelitian ini menggunakan metode Focal Animal Sampling dengan interval waktu 2 menit selama \pm 12 jam selama lebih dari 6 bulan. Orangutan focal yang dicatat aktivitasnya selama penelitian terdiri dari 12 individu yang dibagi menjadi 3 kelompok umur yaitu kelompok umur dewasa, remaja, dan juvenile. Hasil penelitian menunjukkan bahwa data aktivitas harian orangutan tercatat pada 36 jenis pohon dengan frekuensi kehadiran terbesar yaitu pada Garcinia sp. dan Syzigium sp. masing-masing sebesar 33\%. Orangutan betina lebih dominan melakukan aktivitas feeding (3,93 per hari) sedangkan orangutan jantan, lebih banyak melakukan aktivitas resting (4,56 jam per hari). Pemanfaatan ruang vertikal pada orangutan jantan remaja dilakukan di pohon yang tinggi dan melakukan aktivitas makan pada ketinggian 33,6 m. Orangutan betina remaja memilih pohon dengan tinggi $30 \mathrm{~m}$ melakukan aktivitas bersarang.

Katakunci: aktivitas harian, orangutan, ruang vertical, gunung palung

\section{PENDAHULUAN}

Indonesia memiliki ekosistem hutan hujan tropis yang tersebar luas dari Pulau Sumatera, Kalimantan hingga Papua. Ekosistem hutan hujan tropis memiliki keanekaragaman satwa maupun flora yang sangat beragam. Hutan hujan tropis di Pulau Sumatera dan Kalimantan masih terdapat populasi orangutan yang terancam punah (Supriatna dan Wahyono, 2000). Taman Nasional Gunung Palung yang terletak di Kabupaten Kayong Utara dan Kabupaten Ketapang, Provinsi Kalimantan Barat memiliki ekosistem yang beragam yang meliputi delapan ekosistem yang berbeda. Lokasi Taman
Nasional Gunung Palung merupakan habitat orangutan yang masih memiliki banyak populasi orangutan (Setiawan, 2015).

Orangutan merupakan hewan soliter dan mempunyai pola kehidupan yang khas dan berbeda dari jenis kera besar lainnya dari famili Pongidae (Kuncoro, 2004). Dalam hutan Kalimantan, Orangutan Kalimantan yang terdiri dari tiga sub spesies yaitu Pongo pygmaeus wumbii, P. pygmaeus pygmaeus dan $P$. pygmaeus morio berstatus sangat terancam punah. Hal ini disebabkan oleh perburuan liar di Kalimantan untuk menjadikan orangutan sebagai peliharaan. Orangutan melakukan beberapa 
aktivitas sehari-harinya yang meliputi makan, bergerak, istirahat, dan bersarang (Lelono, 1998). Aktivitas orangutan dimulai ketika bangun dari sarang dan kemudian berlanjut sepanjang hari hingga orangutan kembali membuat sarang untuk tidur. Pemanfaatan ruang secara vertikal yang digunakan oleh orangutan adalah mengenai bagaimana orangutan memanfaatkan tajuk pada pohon dalam melakukan aktivitas hariannya (Sapari, 1999). Menurut Rijksen (1978), aktivitas orangutan lebih sering berada di strata tengah hutan, seperti aktivitas makan yang dilakukan hampir di setiap kanopi dibandingkan melakukan aktivitas bergerak.

Penelitian tentang pemanfaatan ruang vertikal pada aktivitas orangutan sangat penting dilakukan dikarenakan ruang lingkup bergerak orangutan yang semakin sempit akibat maraknya illegal loging. Penelitian ini juga diharapkan dapat memberikan informasi kepada masyarakat mengenai pemanfaatan ruang vertikal pada aktivitas harian orangutan serta mendukung upaya konservasi orangutan. Penelitian ini betujuan untuk mengetahui frekuensi kehadiran di pohon, aktivitas harian, dan pemanfaatan ruang vertikal pada aktivitas harian orangutan di habitat alami Stasiun Riset Cabang Panti, Taman Nasional Gunung Palung.

\section{BAHAN DAN CARA KERJA Lokasi penelitian}

Penelitian dilaksanakan di Stasiun Riset Cabang Panti (SRCP) yang terletak di daerah Cabang Panti (Gambar 1) yang secara administrasi terletak di Dusun Tanjung Gunung Desa Sejahtera Kecamatan Sukadana Kabupaten Kayong Utara. Stasiun Riset Cabang Panti merupakan pusat penelitian yang ditunjukkan bagi para peneliti. Secara geografis, SRCP terletak di 113'S,1107 'E yaitu di kaki sebelah barat Gunung Palung (1.116 mdpl) dan Gunung Panti (1.050 mdpl). Sebagian besar kawasan SRCP merupakan hamparan perbukitan dan gunung. Hanya ekosistem rawa gambut dan rawa air tawar yang berada di sebelah barat SPCP yang merupakan hamparan dataran rendah. Gunung Palung dengan ketinggian 1.116 mdpl dan Gunung Panti dengan ketinggian $1.050 \mathrm{mdpl}$ merupakan puncak yang tertinggi pada kawasan ini. Gunung Palung dan Gunung Panti terdiri dari batu-batuan asam intrusif dan plutonik yang mengandung silika. Daerah dataran rendahnya sebagian besar tersusun oleh batuan alluvial quarternary. Juga terdapat sebagian kecil daerah dengan batuan efusit yang tidak terbelah, efusit intermediat, serta batuan-batuan plutonik (Setiawan, 2015).

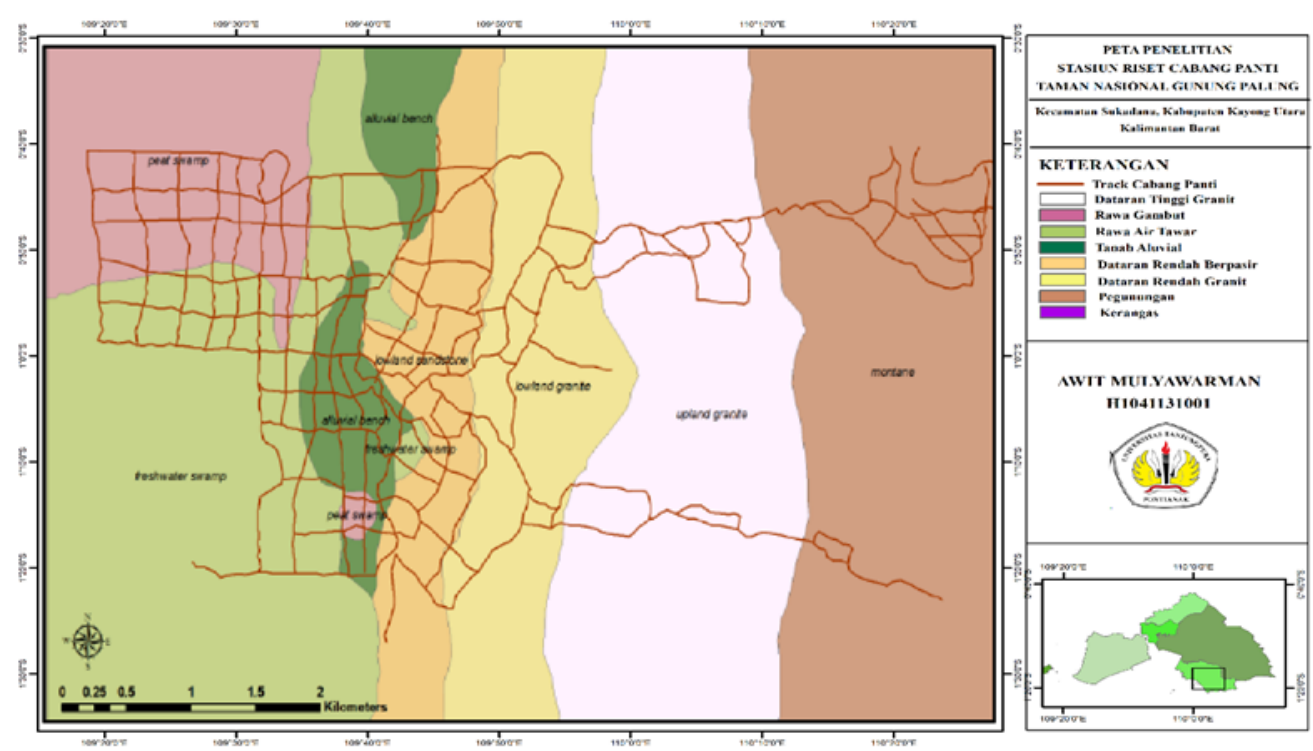

Gambar 1. Peta lokasi penelitian di Taman Nasional Gunung Palung (Map of research location in Gunung Palung National Park) (Setiawan, 2015) 


\section{Metode penelitian}

Penelitian mengenai aktivitas dan perilaku orangutan ini menggunakan metode Focal Animal Sampling. Menurut Altmann (1974), Focal Animal Sampling adalah sebuah metode penelitian yang memfokuskan pada individu sebagai objek dalam pengamatan dan dicatat aktivitasnya mulai dari orangutan memulai aktivitas sampai dengan orangutan tidur kembali dalam interval 2 menit. Selama pencatatan aktivitas, juga dilakukan pengukuran tinggi pohon dan ketinggian kanopi tempat orangutan melakukan aktivitas menggunakan metode estimasi. Hal ini dilakukan agar dapat mengetahui rata-rata ketinggian pohon tempat orangutan melakukan aktivitas. Objek yang digunakan adalah individu orangutan yang ditemukan dalam tahap pencarian dan pohon tempat orangutan melakukan aktivitas untuk diukur ketinggiannya.

\section{Pencarian orangutan}

Pencarian objek orangutan dilakukan dengan cara menelusuri transek secara acak atau dugaan lokasi adanya orangutan. Pencarian dilakukan dengan berjalan pelan namun berkonsentrasi atau menunggu di bawah pohon pakan yang sedang berbuah. Ciri-ciri yang digunakan untuk menentukan tanda keberadaan orangutan adalah suara yang ditimbulkan akibat aktivitas makan, berpindah tempat, atau vokalisasi yang dilakukan oleh orangutan (long call atau kiss squeak) (Yakin, 2013).

\section{Pengumpulan data}

Pengumpulan data dilakukan dengan cara mengikuti orangutan sejak terbangun dari sarang hingga membuat sarang kembali untuk tidur di malam hari. Data yang diambil yaitu data aktivitas orangutan, ketinggian pohon orangutan melakukan aktivitas, dan pada ketinggian berapa orangutan melakukan aktivitas. Individu yang diamati sebanyak 12 individu dan dibagi menjadi 6 individu jantan dan 6 individu betina. Hal ini dikarenakan orangutan tidak menetap di satu wilayah. Kadang individu orangutan dapat menjelajah keluar wilayah Cabang Panti. Pengamatan 1 objek orangutan dibatasi selama 3 hari, sehingga setelah 3 hari dilakukan pencarian dan pengamatan individu baru. Kemudian dilakukan pengambilan data ketinggian orangutan saat berada di atas pohon untuk dapat mengetahui pemanfaatan ruang secara vertikal.

Pengukuran tinggi pohon dilakukan dengan menggunakan metode estimasi dan melihat data tinggi pohon tagging. Data diambil saat orangutan berada di atas pohon. Ketika orangutan berada di ketinggian tertentu, pengukuran dilakukan dan dilihat berapa lama orangutan melakukan aktivitas di ketinggian tersebut. Data juga diambil untuk mengetahui berapa persen orangutan memanfaatkan 1 pohon untuk aktivitasnya.

\section{HASIL}

\section{Frekuensi kehadiran orangutan}

Berdasarkan hasil penelitian yang sudah dilakukan di Stasiun Riset Cabang Panti, Taman Nasional Gunung Palung, tercatat 36 jenis pohon yang dikunjungi orangutan untuk melakukan aktivitasnya (Gambar 2). Orangutan mendatangi suatu pohon dengan frekuensi dan aktivitas yang berbeda. Garcinia sp. dan Syzigium sp. menjadi pohon yang paling sering dikunjungi orangutan untuk beraktivitas (33\%) (Gambar 2). Persentase frekuensi kehadiran yang paling sedikit terjadi pada Uvaria sp., Castanopsis sp., Spatholobus sp., Eusideroxylon sp., Pomettia sp., dan Pythocrane sp. dengan frekuensi kehadiran orangutan sebesar 3\%.

\section{Aktivitas harian orangutan}

Pemanfaatan waktu dalam aktivitas harian orangutan dibagi menjadi 4 kategori aktivitas primer yaitu bangun, makan, istirahat, jalan, dan bersarang. Aktivitas harian antara individu jantan dan betina didominasi oleh aktivitas makan dan istirahat (Gambar 3). Aktivitas makan pada individu orangutan betina menjadi aktivitas dominan yang dilakukan orangutan betina dengan pemanfaatan waktu 3,93 jam. Orangutan jantan memiliki pemanfaatan waktu pada aktivitas makan yang lebih kecil dibandingkan dengan orangutan betina dengan pemanfaatan waktu 3,45 jam. Untuk aktivitas harian, orangutan jantan memiliki pemanfaatan waktu terbesar pada aktivitas istirahat yaitu 4,56 jam, sedangkan orangutan betina memiliki pemanfaatan waktu 3,65 jam. Untuk aktivitas jalan dari pohon ke pohon, orangutan betina memanfaatkan waktu 
Tabel 1. Daftar individu orangutan Focal ((List of focal orangutan individuals)

\begin{tabular}{cccc}
\hline Jenis Kelamin & Kelompok Umur & Jumlah Individu & Nama Individu \\
\hline \multirow{2}{*}{ Jantan } & Jantan dewasa cheek pad & 3 & Alfred, Panchito, Prabu \\
$(\mathrm{n}=6)$ & Jantan dewasa non cheek pad & 1 & Gordon \\
& Jantan remaja & 1 & Bilbo \\
& Jantan juvenile & 1 & Bayas \\
Betina & Betina dewasa & 3 & Bibi, Tari, Rosa \\
$(\mathrm{n}=6)$ & Betina remaja & 2 & Berani, Roni \\
& Betina juvenile & 1 & Tawny \\
\hline
\end{tabular}

Tabel 2. Ketinggian aktivitas orangutan (Height of orangutan activity)

\begin{tabular}{|c|c|c|c|c|c|c|c|c|c|}
\hline \multirow{3}{*}{$\begin{array}{c}\text { Jenis } \\
\text { Kelamin }\end{array}$} & \multirow{3}{*}{$\begin{array}{c}\text { Kelompok } \\
\text { Umur }\end{array}$} & \multirow{3}{*}{$\begin{array}{l}\text { Jumlah } \\
\text { Individu }\end{array}$} & \multirow{3}{*}{$\begin{array}{l}\text { Jumlah } \\
\text { Pohon }\end{array}$} & \multicolumn{6}{|c|}{ Rata-rata tinggi (m) } \\
\hline & & & & \multicolumn{3}{|c|}{ Tinggi Pohon Aktivitas } & \multicolumn{3}{|c|}{ Tinggi Aktivitas } \\
\hline & & & & $\mathrm{F}$ & $\mathrm{R}$ & $\mathrm{N}$ & $\mathrm{F}$ & $\mathrm{R}$ & $\mathrm{N}$ \\
\hline \multirow{4}{*}{$0^{\pi}$} & Juvenile & 1 & 12 & 27,5 & 27,4 & 25,6 & 25,2 & 24,9 & 24,1 \\
\hline & Remaja & 1 & 9 & 36,1 & 30,7 & 23,4 & 33,6 & 26,4 & 21,5 \\
\hline & Dewasa & 4 & 64 & 32,5 & 27,8 & 22,7 & 29,3 & 25,4 & 19,7 \\
\hline & Total & 6 & 85 & & & & & & \\
\hline \multirow{4}{*}{ 우 } & Juvenile & 1 & 10 & 31,2 & 27,4 & 23,4 & 28,5 & 24,4 & 22,7 \\
\hline & Remaja & 2 & 31 & 31,1 & 27,5 & 30 & 28,5 & 25,2 & 22,2 \\
\hline & Dewasa & 3 & 35 & 29,7 & 28,4 & 24,9 & 25,4 & 24,8 & 21,9 \\
\hline & Total & 6 & 76 & & & & & & \\
\hline
\end{tabular}

Keterangan : F: feeding; $R$ : resting; $N$ : nesting

dengan rata-rata sebesar 2,30 jam, sedangkan orangutan jantan memanfaatkan waktu 2,98 jam dalam 1 hari (Gambar 3).

Aktivitas bangun dari sarang dilakukan orangutan jantan dan betina masing-masing memiliki pemanfaatan waktu 0,03 jam. Aktivitas bangun menjadi aktivitas yang paling sedikit dilakukan orangutan dalam 1 hari karena selama pengamatan orangutan bangun dari sarang hanya di saat pagi hari saat mulai diamati (Gambar 3).

\section{Pemanfaatan ruang vertikal}

Orangutan jantan dewasa memiliki preferensi terhadap pohon dengan rata-rata tinggi pohon sebesar 32,5 m untuk aktivitas makan, 27,8 m untuk aktivitas istirahat, dan $22,7 \mathrm{~m}$ untuk aktivitas bersarang (Tabel 2). Masing-masing aktivitas orangutan jantan dilakukan pada ketinggian pohon 29,3 m untuk aktivitas makan, 25,4 m untuk aktivitas istirahat, dan 19,7 m untuk aktivitas bersarang (Tabel 2). Orangutan jantan remaja memiliki preferensi pohon dengan rata-rata tinggi sebesar 36,1 $\mathrm{m}$ untuk aktivitas makan, 30,7 m untuk aktivitas istirahat, dan 23,4 m untuk aktivitas bersarang. Ketinggian pohon pada orangutan jantan remaja saat melakukan aktivitas yaitu 33,6 m untuk aktivitas makan, 26,4 m untuk aktivitas istirahat, dan 21,5 m untuk aktivitas bersarang (Tabel 2). Orangutan jantan juvenile memiliki preferensi pohon dengan rata-rata tinggi sebesar 27,5 m untuk aktivitas makan, 27,4 m untuk aktivitas istirahat, dan 25,6 m untuk aktivitas bersarang, dan orangutan jantan juvenile melakukan aktivitas pada ketinggian 25,2 m untuk makan, 24,9 $\mathrm{m}$ untuk istirahat, dan $24,1 \mathrm{~m}$ untuk bersarang (Tabel 2).

Orangutan betina dewasa memiliki preferensi pohon dengan rata-rata tinggi sebesar 29,7 m untuk aktivitas makan, 28,4 $\mathrm{m}$ untuk aktivitas istirahat, dan $24,9 \mathrm{~m}$ untuk aktivitas bersarang. Orangutan betina dewasa melakukan aktivitas pada ketinggian 25,4 m untuk aktivitas makan, 24,8 m untuk aktivitas istirahat dan 21,9 $\mathrm{m}$ untuk aktivitas bersarang 
Artikel Penelitian

Mulyawarman et al. - Pemanfaatan Ruang Vertikal Pada Aktivitas Harian Orangutan

Tabel 3. Persentase preferensi kehadiran pada orangutan jantan dan betina dalam 1 hari (Percentage of tree preference in male and female individuals in 1 day)

\begin{tabular}{|c|c|c|c|}
\hline Jenis Kelamin & Kelompok Umur & Jumlah Pohon & Preferensi (\%) \\
\hline \multirow[b]{2}{*}{$0^{\pi}$} & Dewasa & 64 & 75 \\
\hline & $\begin{array}{l}\text { Remaja } \\
\text { Juvenile }\end{array}$ & $\begin{array}{c}9 \\
12\end{array}$ & $\begin{array}{l}11 \\
14\end{array}$ \\
\hline \multicolumn{2}{|c|}{ Total Pohon } & 85 & 100 \\
\hline \multirow{3}{*}{ q } & Dewasa & 35 & 46 \\
\hline & Remaja & 31 & 41 \\
\hline & Juvenile & 10 & 13 \\
\hline \multicolumn{2}{|c|}{ Total Pohon } & 76 & 100 \\
\hline
\end{tabular}

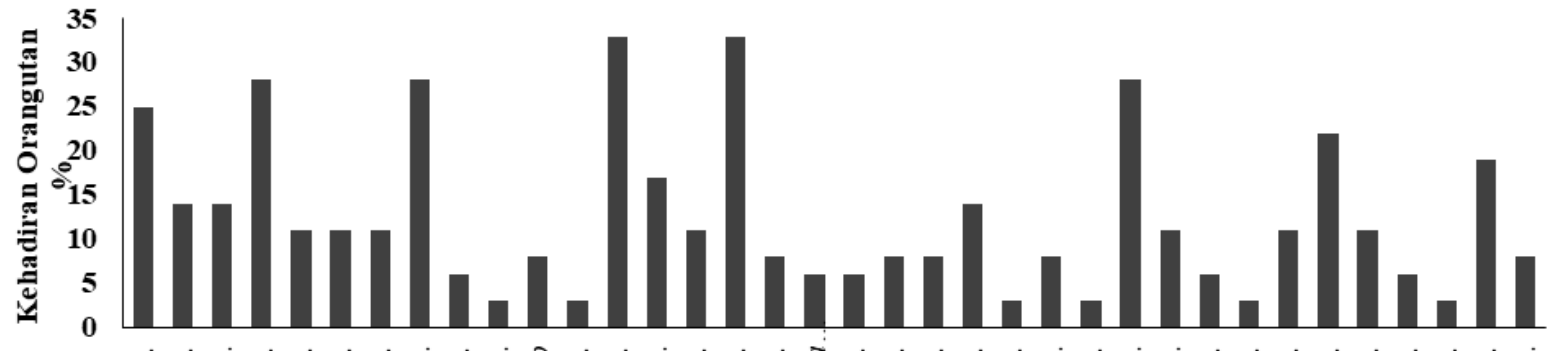

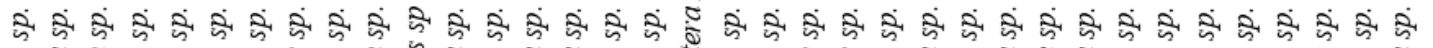

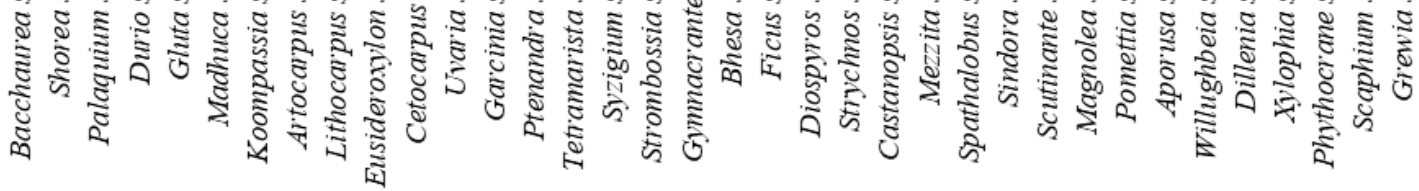

Gambar 2. Frekuensi kehadiran orangutan pada pohon yang ada di Stasiun Riset Cabang Panti (Frequency of orangutan presence on trees at the Panti Branch Research Station)

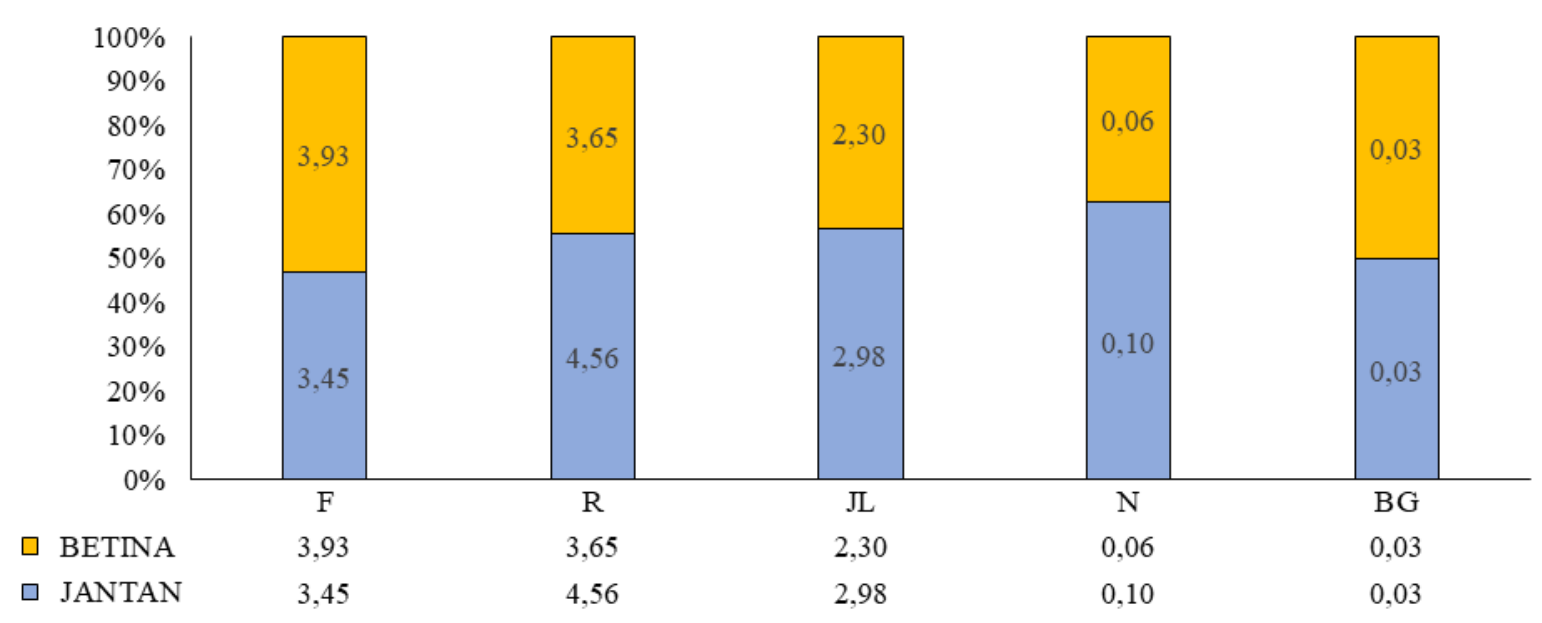

Gambar 3. Pemanfaatan waktu pada aktivitas orangutan (Utilizing time on orangutan activities)

(M: makan; I: istirahat; JL: jalan; S: sarang; BG: bangun) 
(Tabel 2). Orangutan betina remaja memiliki preferensi pohon dengan tinggi rata-rata yaitu 31,1 m untuk aktivitas makan, 27,5 m untuk aktivitas istirahat, dan $30 \mathrm{~m}$ untuk aktivitas bersarang. Ketinggian posisi orangutan betina remaja saat melakukan aktivitas adalah 28,5 m untuk aktivitas makan, 25,2 m untuk aktivitas istirahat, dan 22,2 m untuk aktivitas bersarang (Tabel 2). Orangutan betina juvenile memiliki preferensi pohon dari dengan tinggi rata-rata sebesar 31,2 $\mathrm{m}$ untuk aktivitas makan, 27,4 m untuk aktivitas istirahat, dan 23,4 untuk aktivitas bersarang. Orangutan betina juvenile melakukan aktivitas pada ketinggian 28,5 m untuk aktivitas makan, 24,4 m untuk aktivitas istirahat, dan $22,7 \mathrm{~m}$ untuk bersarang (Tabel 2).

\section{PEMBAHASAN}

\section{Frekuensi kehadiran orangutan}

Garcinia sp. dan Syzigium sp. merupakan pohon yang paling sering dikunjungi orangutan selama pengamatan, dengan persentase $33 \%$ (Gambar 2). Hal ini disebabkan karena pohon Garcinia sp. dan Syzigium sp. merupakan pohon yang berbuah setiap tahun. Hal ini juga sesuai dengan penelitian Knott (1999) yang menyatakan bahwa Garcinia sp. merupakan pohon yang sering dikunjungi oleh orangutan untuk melakukan aktivitas. Artocarpus sp. dan Durio sp. dikunjungi orangutan dengan persentase kehadiran yang lebih rendah yaitu 28\% (Gambar 2). Hal ini disebabkan karena Artocarpus sp. dan Durio sp. merupakan tanaman musiman yang berbuah hanya pada saat panen raya yang berlangsung \pm 4 tahun sekali. Aktivitas dominan di pohon Durio sp. dan pohon Artocarpus sp. adalah aktivitas makan dan istirahat.

Pohon dengan frekuensi kehadiran $<20 \%$ seperti pohon Koompassia sp. dan Shorea sp. adalah pohon yang digunakan orangutan untuk aktivitas istirahat. Selama pengamatan, orangutan tidak memanfaatkan pohon Shorea sp. untuk melakukan aktivitas makan. Hal ini diduga karena orangutan tidak menyukai buah Shorea sp. dan Koompassia sp. Orangutan mendatangi pohon Koompassia sp. dan Shorea sp. untuk melakukan aktivitas istirahat seperti duduk atau membuat sarang siang untuk istirahat. Kecenderungan orangutan mendatangi pohon tertentu, disebabkan oleh musim buah raya yang menyebabkan semua jenis pohon di lokasi penelitian berbuah. Menurut Kuswanda et al. (2004), ketersediaan makanan, air, terjaminnya kemanan dan kenyamanan tempat bersarang adalah faktor utama yang menjadi pertimbangan pemilihan tempat beraktivitas orangutan.

\section{Aktivitas harian orangutan}

Orangutan betina lebih mendominasi aktivitas makan (Gambar 3) dengan pemanfaatan waktu 3,93 jam (Gambar 3), sedangkan orangutan jantan memanfaatkan 3,45 jam proporsi waktu untuk aktivitas makan (Gambar 3). Orangutan betina dewasa dengan juvenile lebih banyak membutuhkan energi untuk menunjang aktivitas hariannya yang didominasi dengan menggendong anak dan melakukan aktivitas food sharing dengan anaknya. Hal ini disebabkan karena orangutan betina dewasa dengan juvenile membutuhkan sumber energi yang besar untuk menunjang aktivitas lainnya (Susanto, 2006). Orangutan jantan lebih sedikit makan karena berkaitan dengan aktivitas istirahat yang lebih banyak dilakukannya. Terdapat perbedaan aktivitas dan pemanfaatan pohon antara orangutan jantan yang mempunyai cheek pad (bantalan pipi) dengan orangutan jantan remaja yang tidak memiliki cheek pad. Seperti Alfred yang merupakan orangutan jantan dominan yang lebih banyak mendominasi pohon pakan dibandingkan dengan Bilbo yang selalu menghindari pertemuan dengan Alfred. Pemilihan dan penguasaan sumber pakan merupakan strategi yang dilakukan sebagian besar primata dalam memenuhi energi yang hilang selama melakukan aktivitas harian (Rikjsen, 1978).

Aktivitas istirahat didominasi oleh orangutan jantan dengan pemanfaatan waktu 4,56 jam (Gambar 3). Hal ini terjadi karena pada saat pengamatan sedang berlangsung musim kawin orangutan, sehingga orangutan jantan selalu mengikuti orangutan betina. Ketika orangutan betina melakukan aktivitas makan, orangutan jantan hanya beristirahat dan tidak melakukan aktivitas makan. Ukuran badan yang besar dan umur 
orangutan jantan juga merupakan faktor utama tingginya aktivitas istirahat pada orangutan jantan (Susanto, 2006).

Orangutan jantan memiliki pemanfaatan waktu pada aktivitas jalan yang lebih lama yaitu 2,98 jam dan orangutan betina sebesar 2,30 jam. Orangutan jantan melakukan aktivitas bergerak dikarenakan kebutuhan makan yang sangat tinggi dalam menunjang kebutuhan nutrisi hariannya (Susanto, 2006). Orangutan jantan akan terus bergerak untuk mendapatkan pohon pakan dengan ketersediaan buah yang tinggi.

\section{Pemanfaatan ruang vertikal}

Berdasarkan pengamatan ketinggian pohon dan ketinggian aktivitas saat melakukan aktivitas, orangutan selalu memilih pohon dengan DBH (Diameter at Breast Height) besar untuk melakukan aktivitas dengan ketinggian maksimal. Orangutan jantan dewasa lebih memilih pohon yang lebih tinggi untuk melakukan aktivitas tertentu. Pemanfaatan ruang vertikal pada orangutan berbeda pada setiap aktivitas dan kelompok umur. Orangutan dibagi menjadi dua kelompok kelamin dan masing-masing kelompok kelamin dibagi menjadi tiga kelompok umur yang diamati (Tabel 1). Pada aktivitas makan orangutan jantan dewasa memilih pohon dengan tinggi rata-rata 32,5 $\mathrm{m}$ dan melakukan aktivitas makan pada ketinggian 29,3 m (Tabel 2). Hal ini disebabkan rata-rata orangutan focal merupakan orangutan jantan dominan memilih pohon dengan ketinggian maksimal yang memiliki sediaan buah pakan yang melimpah pada puncak pohon. Orangutan jantan juga melakukan aktivitas vokalisasi setelah makan dengan melakukan long call (panggilan panjang) untuk menunjukkan keberadaannya pada orangutan jantan lain.

Orangutan betina dewasa melakukan aktivitas pada pohon yang memiliki tinggi $29,7 \mathrm{~m}$ dan melakukan aktivitas makan dengan ketinggian 25,4 $\mathrm{m}$ (Tabel 2). Orangutan betina dewasa selalu membawa bayi saat beraktivitas. Insting untuk melindungi dan menjaga anak yang selalu bermain pada ranting yang tidak terlalu tinggi adalah faktor penyebab orangutan betina dewasa melakukan aktivitas makan pada ketinggian $<30 \quad \mathrm{~m}$
(Djojosudharmo, 1978). Orangutan betina remaja dan juvenile memiliki rata-rata tinggi pohon aktivitas yang sama yaitu $31 \mathrm{~m}$ (Tabel 2). Aktivitas makan orangutan betina remaja dan juvenile dilakukan pada ketinggian 28,5 m (Tabel 2). Orangutan betina remaja cenderung memilih pohon tinggi untuk melakukan aktivitas karena orangutan betina remaja membutuhkan pakan yang lebih banyak untuk menunjang aktivitasnya. Orangutan betina remaja dapat berpindah dengan cepat dari satu pohon kepohon lain ketika buah di pohon tersebut telah habis.

\section{KESIMPULAN}

Orangutan di habitat alami Stasiun Riset Cabang Panti, Taman Nasional Gunung melakukan aktivitas harian pada 36 jenis pohon dengan frekuensi kehadiran terbesar yaitu pada Garcinia sp. dan Syzigium sp. sebesar 33\%. Orangutan betina lebih dominan melakukan aktivitas feeding sebesar $34,8 \%$, sedangkan orangutan jantan, lebih banyak melakukan aktivitas resting sebesar 39,9\%. Orangutan jantan remaja memilih pohon dengan tinggi $36,1 \mathrm{~m}$ dan melakukan aktivitas makan pada ketinggian 33,6 m, sedangkan orangutan betina remaja memilih pohon yang tinggi dan melakukan aktivitas bersarang pada ketinggian $30 \mathrm{~m}$.

Saran yang dapat diberikan untuk penelitian tentang orangutan di Stasiun Riset Cabang Panti, Taman Nasional Gunung Palung yaitu perlu dilakukan penelitian lebih lanjut untuk pemanfaatan ruang horizontal pada aktivitas harian orangutan.

\section{UCAPAN TERIMA KASIH}

Penulis mengucapkan terima kasih dan penghargaan kepada Yayasan Palung, Stasiun Riset Cabang Panti dan pihak Taman Nasional Gunung Palung yang telah memberikan izin dan memfasilitasi selama kegiatan riset berlangsung.

\section{DAFTAR PUSTAKA}

Altmann, J., 1974. Observation Study of Behaviour Sampling Methods, Journal of Laboratory Animal Behaviour, University of Chicago, Chicago, Illinois, U.S.A.

Atmoko, U., 2000. Bimaturism in Orangutan Males, Phd Thesis, Uthrech University, Netherland.

Bismark, M., 1984. Biologi dan Konservasi Primata di Indonesia, Fakultas Pasca Sarjana IPB, Bogor.

Djojosudharmo, S., 1978. Beberapa aspek tingkah laku 
orangutan (Pongo pygmaeus Linne. 1760), Universitas Nasional Jakarta, Jakarta.

Galdikas, B.M.F., 1986. Adaptasi Orangutan di Suaka Tanjung Putting, Kalimantan Tengah, UI Press, Jakarta.

Groves, C.P., 2001. Primate Taxonomy, Smithsonian Institution Press. Washington and London.

Knott, C.D., 1998. Changes in Orangutan Caloric Intake, Energy Balance, and Ketones in Response to Fluctuating Fruit Availability, Internasional Journal of Primatology, pp. 50-57.

Knott, C.D., 1999. Reproductive, physiological and behavioral responses of orangutans in Borneo to fluctuations in food availability, Ph.D. Dissertation, Harvard University: $\mathrm{x}+373 \mathrm{hlm}$.

Kuncoro, P. 2004. Aktivitas harian orangutan Kalimantan (Pongo pygmaeus Linnaeus, 1760) rehabilitan di Hutan Lindung Pegunungan Meratus, Kalimantan Timur, Skripsi, Jurusan Biologi, Fakultas Matematika dan Ilmu Pengetahuan Alam, Universitas Udayana, Bali.

Lelono, J., 1998, Aktivitas dan jelajah harian pada orangutan jantan pradewasa (Pongo pygmaeus pygmaeus, Linnaeus, 1769). Jurnal Ilmiah, Fakultas Biologi Universitas Nasional, Jakarta

Mackinnon, J.R., 1972. The Behaviour and Ecology of the Orangutan (Pongo pygmaues) with Relation to the Other Apes. University of Oxford. Michaelmas Term., p. 10.

Mackinnon, J.R., 1974. Comperative Feeding Ecology of Six Simpatric Primates in West Malaysia,. vol 1. Academis Press, London. 1978, h. 305-321.

Maple, T.L., 1980. Orangutan Behaviour. Van Nostrand Reinhold Company, New York.

Maryati, Y.I., 2002. Perilaku sosial orangutan (Pongo pygmaeus) anak berdasarkan perbedaan tingkatan umur. Jurnal Ilmiah. Fakultas Biologi. Universitas Nasional, Jakarta.

Meijaard, E., Rijksen, H.D. dan Kartikasari, S.N., 2001. Di Ambang Kepunahan. Kondisi Orangutan Liar di Abad ke-21, The Gibbon Foundation Indonesia, Jakarta.

Rijksen, H.D., 1978. Field Study on Sumatera Orangutan (Pongo pygmaeus abelii, Lesson 1827): Ecology, Behaviour and Conservation. Dissertation Agricultural, Wageningen University.
Rodman, P.S., 1973. Synecology of Borneon Primates. Dissertation, Harvard University.

Rodman, P.S., 1979. Individual Activity Pattern and Solitary Nature of Orangutans. In: Great Apes. Hamburg, D.A. and McCown, E.R. (ed.).The Benjamin Cummings Publising Company. Menlo Park, California.

Sapari, I., 1999. Pemanfaatan Ruang dalam Aktivitas Harian oleh Orangutan (Pongo pygmaeus)', Jurnal Ilmiah, Fakultas Biologi, Universitas Nasional, Jakarta.

Sariningsih, S.S., 2003. Aktivitas Makan Orangutan (Pongo abelii) Betina di Dalam dan di Luar Kawasan Tempa Pemberian Makan Orangutan di Stasiun Rehabilitas Orangutan, Bahorok, Taman Nasional Gunung Leuser, Sumatera Utara. Skripsi. Fakultas Biologi. Universitas Nasional, Jakarta.

Schurmann, C.L., 1982. Mating Behavior of Wild Orangutan dalam The Orangutan, its Biology and Coservation, Liem De Boer (Eds.), The Hague, W Junk. pp. 269284

Setiawan, E., 2015. Stasiun Penelitian Cabang Panti The Heaven of Science, Balai Taman Nasional Gunung Palung, Sukadana.

Sugardjito, J., 1983. Locomotor Behaviour of the Sumatra Orangutan (Pongo pygmaues abelli, 1827) at Ketambe, Gunung Leuser National Park Malay.

Sugardjito, J., 1986. Ecologycal Constrains on The Behaviour of Sumatran Orangutan (Pongo pygmaeus abelli, 1872) in the Gunung Leuser National Park. Indonesia. Thesis, Drukkerij Press Trajectina, Utrech, h.102.

Sugardjito, J., 1988., Use of Forest Strata by the Sumatran Orangutans' A Consideration of Functional Aspect, Treumbia, 29 , p. 235 .

Supriatna, J. dan Wahyono, E.H., 2000. Panduan Lapangan Primata Indonesia. Yayasan Obor Indonesia, Jakarta.

Susanto, T. W. 2006. Pemanfaatan Ruang Aktivitas Harian Antar Individu Orangutan (Pongo pygmaeus wurmbii, TIEDEMANN 1808) Jantan di Stasiun Penelitian Orangutan Tuanan, Skripsi. Kalimantan Tengah.

Yakin, M. R., 2013. Perilaku Bersarang Orangutan Kalimantan (Pongo pygmaeus wurmbii) di Tipe Habitat Berbeda di Stasiun Penelitian Cabang Panti,Taman Nasional Gunung Palung,Kalimantan Barat. Fakultas Sains dan Teknologi. Skripsi. Universitas Islam Negeri Syarif Hidayatullah, Jakarta. 


\section{Pedoman Penulisan Naskah Berita Biologi}

Berita Biologi adalah jurnal yang menerbitkan artikel kemajuan penelitian di bidang biologi dan ilmu-ilmu terkait di Indonesia. Berita Biologi memuat karya tulis ilmiah asli berupa makalah hasil penelitian, komunikasi pendek dan tinjauan kembali yang belum pernah diterbitkan atau tidak sedang dikirim ke media lain. Masalah yang diliput harus menampilkan aspek atau informasi baru.

\section{Tipe naskah}

1. Makalah lengkap hasil penelitian (original paper)

Naskah merupakan hasil penelitian sendiri yang mengangkat topik yang up to date. Tidak lebih dari 15 halaman termasuk tabel dan gambar. Pencantuman lampiran seperlunya, namun redaksi berhak mengurangi atau meniadakan lampiran.

2. Komunikasi pendek (short communication)

Komuniasi pendek merupakan makalah hasil penelitian yang ingin dipublikasikan secara cepat karena hasil termuan yang menarik, spesifik dan atau baru, agar dapat segera diketahui oleh umum. Hasil dan pembahasan dapat digabung.

3. Tinjauan kembali (review)

Tinjauan kembali merupakan rangkuman tinjauan ilmiah yang sistematis-kritis secara ringkas namun mendalam terhadap topik penelitian tertentu. Hal yang ditinjau meliputi segala sesuatu yang relevan terhadap topik tinjauan yang memberikan gambaran 'state of the art', meliputi temuan awal, kemajuan hingga issue terkini, termasuk perdebatan dan kesenjangan yang ada dalam topik yang dibahas. Tinjauan ulang ini harus merangkum minimal 30 artikel.

\section{Struktur naskah}

1. Bahasa

Bahasa yang digunakan adalah Bahasa Indonesia atau Inggris yang baik dan benar

2. Judul

Judul diberikan dalam bahasa Indonesia dan inggris. Judul ditulis dalam huruf tegak kecuali untuk nama ilmiah yang menggunakan bahasa latin, Judul harus singkat, jelas dan mencerminkan isi naskah dengan diikuti oleh nama serta alamat surat menyurat penulis dan alamat email. Nama penulis untuk korespondensi diberi tanda amplop cetak atas (superscript). Jika penulis lebih dari satu orang bagi pejabat fungsional penelitian, pengembangan agar menentukan status sebagai kontributor utama melalui penandaan simbol dan keterangan sebagai kontributor utama dicatatan kaki di halaman pertama artikel.

3. Abstrak

Abstrak dibuat dalam dua bahasa, bahasa Indonesia dan Inggris. Abstrak memuat secara singkat tentang latar belakang, tujuan, metode, hasil yang signifikan, kesimpulan dan implikasi hasil penelitian. Abstrak berisi maksimum 200 kata, spasi tunggal. Di bawah abstrak dicantumkan kata kunci yang terdiri atas maksimum enam kata, dimana kata pertama adalah yang terpenting. Abstrak dalam Bahasa Inggris merupakan terjemahan dari Bahasa Indonesia. Editor berhak untuk mengedit abstrak demi alasan kejelasan isi abstrak.

4. Pendahuluan

Pendahuluan berisi latar belakang, permasalahan dan tujuan penelitian. Perlu disebutkan juga studi terdahulu yang pernah dilakukan terkait dengan penelitian yang dilakukan.

5. Bahan dan cara kerja

Bahan dan cara kerja berisi informasi mengenai metode yang digunakan dalam penelitian. Pada bagian ini boleh dibuat sub-judul yang sesuai dengan tahapan penelitian. Metoda harus dipaparkan dengan jelas sesuai dengan standar topik penelitian dan dapat diulang oleh peneliti lain. Apabila metoda yang digunakan adalah metoda yang sudah baku cukup ditulis sitasinya dan apabila ada modifikasi maka harus dituliskan dengan jelas bagian mana dan hal apa yang dimodifikasi.

6. Hasil

Hasil memuat data ataupun informasi utama yang diperoleh berdasarkan metoda yang digunakan. Apabila ingin mengacu pada suatu tabel/ grafik/diagram atau gambar, maka hasil yang terdapat pada bagian tersebut dapat diuraikan dengan jelas dengan tidak menggunakan kalimat 'Lihat Tabel 1'. Apabila menggunakan nilai rata- rata maka harus menyertakan pula standar deviasinya.

7. Pembahasan

Pembahasan bukan merupakan pengulangan dari hasil. Pembahasan mengungkap alasan didapatkannya hasil dan arti atau makna dari hasil yang didapat tersebut. Bila memungkinkan, hasil penelitian ini dapat dibandingkan dengan studi terdahulu.

8. Kesimpulan

Kesimpulan berisi infomasi yang menyimpulkan hasil penelitian, sesuai dengan tujuan penelitian, implikasi dari hasil penelitian dan penelitian berikutnya yang bisa dilakukan.

9. Ucapan terima kasih

Bagian ini berisi ucapan terima kasih kepada suatu instansi jika penelitian ini didanai atau didukungan oleh instansi tersebut, ataupun kepada pihak yang membantu langsung penelitian atau penulisan artikel ini.

10. Daftar pustaka

Tidak diperkenankan untuk mensitasi artikel yang tidak melalui proses peer review. Apabila harus menyitir dari "laporan" atau "komunikasi personal" dituliskan 'unpublished' dan tidak perlu ditampilkan di daftar pustaka. Daftar pustaka harus berisi informasi yang up to date yang sebagian besar berasal dari original papers dan penulisan terbitan berkala ilmiah (nama jurnal) tidak disingkat.

\section{Format naskah}

1. Naskah diketik dengan menggunakan program Microsoft Word, huruf New Times Roman ukuran 12, spasi ganda kecuali Abstrak spasi tunggal. Batas kiri-kanan atas-bawah masing-masing 2,5 cm. Maksimum isi naskah 15 halaman termasuk ilustrasi dan tabel.

2. Penulisan bilangan pecahan dengan koma mengikuti bahasa yang ditulis menggunakan dua angka desimal di belakang koma. Apabila menggunakan Bahasa Indonesia, angka desimal ditulis dengan menggunakan koma (,) dan ditulis dengan menggunakan titik (.) bila menggunakan bahasa Inggris. Contoh: Panjang buku adalah 2,5 cm. Lenght of the book is $2.5 \mathrm{~cm}$. Penulisan angka 1-9 ditulis dalam kata kecuali bila bilangan satuan ukur, sedangkan angka 10 dan seterusnya ditulis dengan angka. Contoh lima orang siswa, panjang buku $5 \mathrm{~cm}$.

3. Penulisan satuan mengikuti aturan international system of units.

4. Nama takson dan kategori taksonomi ditulis dengan merujuk kepada aturan standar yang diakui. Untuk tumbuhan menggunakan International Code of Botanical Nomenclature (ICBN), untuk hewan menggunakan International Code of Zoological Nomenclature (ICZN), untuk jamur International Code of Nomenclature for Algae, Fungi and Plant (ICFAFP), International Code of Nomenclature of Bacteria (ICNB), dan untuk organisme yang lain merujuk pada kesepakatan Internasional. Penulisan nama takson lengkap dengan nama author hanya dilakukan pada bagian deskripsi takson, misalnya pada naskah taksonomi. Penulisan nama takson untuk bidang lainnya tidak perlu menggunakan nama author.

5. Tata nama di bidang genetika dan kimia merujuk kepada aturan baku terbaru yang berlaku.

6. Untuk range angka menggunakan en dash (-), contohnya pp.1565-1569, jumlah anakan berkisar 7-8 ekor. Untuk penggabungan kata menggunakan hyphen (-), contohnya: masing-masing.

7. Ilustrasi dapat berupa foto (hitam putih atau berwarna) atau gambar tangan (line drawing).

8. Tabel

Tabel diberi judul yang singkat dan jelas, spasi tunggal dalam bahasa Indonesia dan Inggris, sehingga Tabel dapat berdiri sendiri. Tabel diberi nomor urut sesuai dengan keterangan dalam teks. Keterangan Tabel diletakkan di bawah Tabel. Tabel tidak dibuat tertutup dengan garis vertikal, hanya menggunakan garis horisontal yang memisahkan judul dan batas bawah. 
8. Gambar

Gambar bisa berupa foto, grafik, diagram dan peta. Judul gambar ditulis secara singkat dan jelas, spasi tunggal. Keterangan yang menyertai gambar harus dapat berdiri sendiri, ditulis dalam bahasa Indonesia dan Inggris. Gambar dikirim dalam bentuk .jpeg dengan resolusi minimal 300 dpi, untuk line drawing minimal 600dpi.

9. Daftar Pustaka

Sitasi dalam naskah adalah nama penulis dan tahun. Bila penulis lebih dari satu menggunakan kata 'dan' atau et al. Contoh: (Kramer, 1983), (Hamzah dan Yusuf, 1995), (Premachandra et al., 1992). Bila naskah ditulis dalam bahasa Inggris yang menggunakan sitasi 2 orang penulis maka digunakan kata 'and'. Contoh: (Hamzah and Yusuf, 1995). Jika sitasi beruntun maka dimulai dari tahun yang paling tua, jika tahun sama maka dari nama penulis sesuai urutan abjad. Contoh: (Anderson, 2000; Agusta et al., 2005; Danar, 2005). Penulisan daftar pustaka, sebagai berikut:

a. Jurnal

Nama jurnal ditulis lengkap.

Agusta, A., Maehara, S., Ohashi, K., Simanjuntak, P. and Shibuya, H., 2005. Stereoselective oxidation at C-4 of flavans by the endophytic fungus Diaporthe sp. isolated from a tea plant. Chemical and Pharmaceutical Bulletin, 53(12), pp.1565-1569.

b. Buku

Anderson, R.C. 2000. Nematode Parasites of Vertebrates, Their Development and Tramsmission. 2nd ed. CABI Publishing. New York. pp. 650 .

c. Prosiding atau hasil Simposium/Seminar/Lokakarya.

Kurata, H., El-Samad, H., Yi, T.M., Khammash, M. and Doyle, J., 2001. Feedback Regulation of the Heat Shock Response in Eschericia coli. Proceedings of the 40th IEEE Conference on Decision and Control. Orlando, USA. pp. 837-842.

d. Makalah sebagai bagian dari buku

Sausan, D., 2014. Keanekaragaman Jamur di Hutan Kabungolor, Tau Lumbis Kabupaten Nunukan, Kalimanan Utara. Dalam: Irham, M. \& Dewi, K. eds. Keanekaraman Hayati di Beranda Negeri. pp. 47-58. PT. Eaststar Adhi Citra. Jakarta.

e. Thesis, skripsi dan disertasi

Sundari, S., 2012. Soil Respiration and Dissolved Organic Carbon Efflux in Tropical Peatlands. Dissertation. Graduate School of Agriculture. Hokkaido University. Sapporo. Japan.

f. Artikel online.

Artikel yang diunduh secara online ditulis dengan mengikuti format yang berlaku untuk jurnal, buku ataupun thesis dengan dilengkapi alamat situs dan waktu mengunduh. Tidak diperkenankan untuk mensitasi artikel yang tidak melalui proses peer review misalnya laporan perjalanan maupun artikel dari laman web yang tidak bisa dipertangung jawabkan kebenarannya seperti wikipedia.

Himman, L.M., 2002. A Moral Change: Business Ethics After Enron. San Diego University Publication. http:ethics.sandiego.edu/LMH/ oped/Enron/index.asp. (accessed 27 Januari 2008) bila naskah ditulis dalam bahasa inggris atau (diakses 27 Januari 2008) bila naskah ditulis dalam bahasa indonesia

Formulir persetujuan hak alih terbit dan keaslian naskah

Setiap penulis yang mengajukan naskahnya ke redaksi Berita Biologi akan diminta untuk menandatangani lembar persetujuan yang berisi hak alih terbit naskah termasuk hak untuk memperbanyak artikel dalam berbagai bentuk kepada penerbit Berita Biologi. Sedangkan penulis tetap berhak untuk menyebarkan edisi cetak dan elektronik untuk kepentingan penelitian dan pendidikan. Formulir itu juga berisi pernyataan keaslian naskah yang menyebutkan bahwa naskah adalah hasil penelitian asli, belum pernah dan tidak sedang diterbitkan di tempat lain serta bebas dari konflik kepentingan.

\section{Penelitian yang melibatkan hewan}

Setiap naskah yang penelitiannya melibatkan hewan (terutama mamalia) sebagai obyek percobaan/penelitian, wajib menyertakan 'ethical clearance approval' terkait animal welfare yang dikeluarkan oleh badan atau pihak berwenang.

\section{Lembar ilustrasi sampul}

Gambar ilustrasi yang terdapat di sampul jurnal Berita Biologi berasal dari salah satu naskah yang dipublikasi pada edisi tersebut. Oleh karena itu, setiap naskah yang ada ilustrasinya diharapkan dapat mengirimkan ilustrasi atau foto dengan kualitas gambar yang baik dengan disertai keterangan singkat ilustrasi atau foto dan nama pembuat ilustrasi atau pembuat foto.

\section{Proofs}

Naskah proofs akan dikirim ke penulis dan penulis diwajibkan untuk membaca dan memeriksa kembali isi naskah dengan teliti. Naskah proofs harus dikirim kembali ke redaksi dalam waktu tiga hari kerja.

\section{Naskah cetak}

Setiap penulis yang naskahnya diterbitkan akan diberikan 1 eksemplar majalah Berita Biologi dan reprint. Majalah tersebut akan dikirimkan kepada corresponding author

\section{Pengiriman naskah}

Naskah dikirim secara online ke website berita biologi: http://e-journal.biologi.lipi.go.id/index.php/berita_biologi

\section{Alamat kontak}

Redaksi Jurnal Berita Biologi, Pusat Penelitian Biologi-LIPI

Cibinong Science Centre, Jl. Raya Bogor Km. 46 Cibinong 16911

Telp: +61-21-8765067, Fax: +62-21-87907612, 8765063, 8765066,

Email: berita.biologi@mail.lipi.go.id

jurnalberitabiologi@yahoo.co.id atau

jurnalberitabiologi@gmail.com 


\section{BERITA BIOLOGI}

\section{MAKALAH HASIL RISET (ORIGINAL PAPERS)}

EVALUASI PERFORMA PERTUMBUHAN DAN HETEROSIS PERSILANGAN ANTARA IKAN NILA NIRWANA (Oreochromis niloticus) BETINA DENGAN IKAN NILA BIRU (Oreochromis aureus) JANTAN F2 PADA KONDISI TAMBAK HIPERSALINITAS [Evaluation of Growth Performance and Heterosis of Hybridization Between Female Nile Tilapia (Oreochromis niloticus) with Male Blue Tilapia (Oreochromis aureus) F2 on Hipersalinity Brakish Water Pond] Adam Robisalmi, Bambang Gunadi, dan Priadi Setyawan

KINERJA PERBEDAAN SALINITAS TERHADAP RESPON PERTUMBUHAN DAN GAMBARAN DARAH BENIH IKAN TAMBAKAN (Helostoma temminckii) [Salinity Difference Performance on Growth Response and Blood Description of Kissing Gourami (Helostoma temminckii)]

Lies Setijaningsih, Imam Taufik, Deni Radona, dan Mulyasari

PEMANFAATAN RUANG VERTIKAL PADA AKTIVITAS HARIAN ORANGUTAN (Pongo pygmaeus wurmbii) DI STASIUN RISET CABANG PANTI TAMAN NASIONAL GUNUNG PALUNG,

KALIMANTAN BARAT [Utilization of Vertical Spaces in Orangutans (Pongo pygmaeus wurmbii) Daily

Activities in Cabang Panti Research Station, Gunung Palung National Park, West Kalimantan]

Awit Mulyawarman, Tri Rima Setyawati, dan Riyandi

RAGAM FENOTIPE IKAN TENGADAK Barbonymus schwanenfeldii (BLEEKER, 1854) HASIL SILANG LUAR [Phenotype Variation of the Tinfoil Barb Barbonymus schwanenfeldii (Bleeker, 1854) from Outbreed Result]

Firda Amalia Sukma, M.H. Fariddudin Ath-Thar,Odang Carman, dan Deni Radona

AKTIVITAS ANTIBAKTERI DAN ANTIOKSIDAN EKSTRAK TUMBUHAN Ixora cumingiana

[Antibacterial and Antioxidant Activities of Ixora cumingiana Plant Extracts]

Kartika Dyah Palupi, Praptiwi, Dewi Wulansari, dan Andria Agusta.....

PENGARUH PEMAPARAN MEDAN MAGNET 0.2 mT PADA MEDIA YANG MENGANDUNG LOGAM (AI, $\mathrm{Pb}, \mathrm{Cd}$, dan Cu) TERHADAP Bacillus sp. DALAM MENGHASILKAN PROTEASE

[The Influence of 0.2 Mt Magnetic Field Exposure on Media Containing Metal (Al, Pb, Cd, and Cu) on Bacillus sp. in the Producing of Protease]

Sumardi, Rochmah Agustrina, Bambang Irawan, dan Shofia Rodiah

STUDI ETNOEKOLOGI MASYARAKAT ADAT TRAH BONOKELING DI BANYUMAS DAN CILACAP

[Ethnoecology Study on Trah Bonokeling Indigenous Society in Banyumas and Cilacap]

Indah A. Sari, Sulistijorini, dan Y. Purwanto....

AKTIVITAS ANTIBAKTERI EKSTRAK KULTUR JAMUR ENDOFIT Fusarium sp. CSP-4 YANG DIISOLASI DARI Curcuma sumatrana Miq. [Antibacterial Activity of Endophytic Fungus Fusarium sp. CSP-4 Culture Extract Isolated from Curcuma sumatrana Miq.]

Dewi Wulansari, Ersaliany N.P.Q, Bodhi Dharma, Andi Saptaji Kamal, Lukman Hafid, Lina Marlina, dan Praptiwi .....

EVALUATION OF POD SHATTERING RESISTANCE AND AGRONOMIC PERFORMANCE OF SEVERAL SOYBEAN PROMISING LINES [Evaluasi Ketahanan Pecah Polong dan Keragaan Karakter Agronomi Beberapa Galur Harapan Kedelai]

Ayda Krisnawati, M. Muchlish Adie, and Dotti Suryati

Odontochilus uniflorus (BLUME) H. $\bar{E}$. PEDERSEN \& ORMEROD: A NEW ADDITION OF THE

JEWEL ORCHIDS FOR FLORA OF JAVA [Odontochilus uniflorus (Blume) H. $\bar{E}$. Pedersen \& Ormerod:

Penambahan Jenis Anggrek Mutiara Bagi Flora Jawa]

Lina Susanti Juswara

THE PREDICTED STRUCTURE FOR THE ANTI-SENSE SIRNA OF THE RNA POLYMERASE ENZYME (RDRP) GENE OF THE SARS-COV-2 [Prediksi Struktur Anti-Sense siRNA Gen RNA Polymerase Enzyme (RdRp) Virus SARS-CoV-2]

Arli Aditya Parikesit and Rizky Nurdiansyah

KOMUNIKASI PENDEK (SHORT COMMUNICATION)

RAPID SURVEYS REVEAL HEALTHY CORAL-SPONGE COMMUNITIES ON KRAKATAU REEFS [Kaji Cepat Ungkap Kondisi Sehat Komunitas Spons Karang Pada Terumbu Karang Kepulauan Krakatau] 